\title{
MINAT BACA MAHASISWA FAKULTAS ILMU TARBIYAH DAN KEGURUAN IAIN SYEKH NURJATI CIREBON
}

\author{
Lilik Herawati \\ Jurusan Tadris Bahasa Indonesia, IAIN Syekh Nurjati Cirebon \\ lilikher74@gmail.com
}

\begin{abstract}
ABSTRAK
Kajian Perpustakaan Nasional menyimpulkan bahwa masyarakat memiliki minat baca dengan kategori rendah. Penelitian ini menggunakan pendekatan deskriptif eksplanatif yang dilaksanakan selama Agustus sampai November 2018. Data diperoleh melalui angketdan wawancara tertutup. Populasi meliputi seluruh mahasiswa FITK IAIN Syekh Nurjati Cirebon. Adapun sampel berjumlah 100 mahasiswa yang dipilih secara acak dari 10 jurusan di IAIN Syekh Nurjati Cirebon. Validitas data dilakukan dengan triangulasi sumber, triangulasi metode, triangulasi peneliti, dan triangulasi teori. Berdasarkan data dan analisis di atas dapat disimpulkan bahwa minat baca mahasiswa FITK IAIN Syekh Nurjati Cirebon masih tergolong rendah. Hal ini dapat diketahui dari: 1) aktivitas yang dilakukan ketika memiliki waktu luang, 2) jumlah buku yang telah dibaca, 3) kunjungan ke perpustakaan, serta 4) jenis buku yang dibaca. Adapun faktor yang memengaruhi minat baca mahasiswa FITK IAIN Syekh Nurjati Cirebon adalah motivasi dari dalam diri dan motivasi dari luar, seperti: ketersediaan dana, koleksi buku.
\end{abstract}

Kata Kunci: mahasiswa, membaca, motivasi

ABSTRACT
The National Library Study concluded that the community has a low interest in reading interest. This study used an explanatory descriptive approach that was carried out during August to November 2018. Data was obtained through questionnaires and closed interviews. The population includes all FITK IAIN Sheikh Nurjati Cirebon students. The sample is 100 students randomly selected from 10 majors at IAIN Sheikh Nurjati Cirebon. Data validity was done by source triangulation, method triangulation, researcher triangulation, and theory triangulation. Based on the data and analysis above, it can be concluded that the reading interest of the FITK students of Syekh Nurjati Cirebon IAIN is still relatively low. This can be known from: 1) activities carried out when having free time, 2) number of books that have been read, 3) visits to the library, and 4) type of book read. The factors that influence the reading interest of Sheikh Nurjati Cirebon FITK IAIN students are internal motivation and external motivation, such as: availability of funds, collection of books.

Keywords: student, reading, motivation 
Hasil survei Badan Pusat Statistik (BPS) tahun 2012 menunjukkan bahwa 91,58 \% penduduk di atas 10 tahun lebih suka melihat televisi (Kompas, 2016). Penduduk yang suka membaca, baik buku, surat kabar, maupun majalah hanya $17,58 \%$. Hal ini mengisyaratkan bahwa penduduk Indonesia masih rendah dalam minat baca. Padahal seperti telah diketahui bersama, membaca merupakan jendela dunia. Berbagai informasi dapat diperoleh melalui membaca. Temuan BPS ternyata sejalan dengan hasil kajian Perpustakaan Nasional yang dilakukan tahun 2015. Perpustakaan Nasional melakukan kajian di 12 provinsi dan 28 kabupaten atau kota di seluruh wilayah Indonesia. Kajian Perpustakaan Nasional menyimpulkan bahwa masyarakat memiliki minat baca dengan kategori rendah, yakni 25,1. Jumlah ini tentu saja sangat memprihatinkan (Kompas, 2016).

Minat merupakan kecenderungan hati yang tinggi terhadap sesuatu (KBBI, 2015). Minat ditandai dengan suka rela dan tanpa paksaan. Seseorang yang berminat terhadap sesuatu dapat diketahui dari perhatian yang diberikan. Minat berasal dari diri sendiri dan bukan paksaan dari pihak mana pun. Menurut Prasetyono (2016), minat merupakan sebuah perasaan yang diwujudkan dalam sebuah kegiatan. Hal ini menunjukkan bahwa pada mulanya, minat berasal dari dalam diri dan bersifat abstrak. Namun, minat itu kemudian diwujudkan dalam bentuk aktivitas. Minat juga dapat dikatakan sebagai sumber motivasi seseorang untuk melakukan sesuatu. Minat diartikan juga sebagai sikap yang berupa pola perhatian seseorang secara terus-menerus terhadap suatu objek (Chaplin, 2008). Berdasarkan pernyataan tersebut dapat diketahui bahwa minat berciri terus-menerus. Artinya, adanya minat dapat mendorong seseorang untuk melakukan suatu aktivitas secara terusmenerus. Aktivitas ini tentu saja memiliki suatu nilai dan sangat berharga.

Adapun faktor yang memengaruhi minat, meliputi: faktor dari dalam dan dari luar. Beberapa keadaan yang turut memengaruhi minat seseorang, yakni: 1) status ekonomi, 2) pendidikan, 3) lingkungan, serta 4) keadaan psikis. Untuk mengetahui faktorfaktor yang memengaruhi minat dapat dilakukan melalui tes dan non-tes. Membaca merupakan salah satu keterampilan berbahasa. Seperti telah diketahui bersama bahwa keterampilan berbahasa, meliputi: mendengarkan, membaca, berbicara, dan menulis. Pada dasarnya, membaca bukan hanya proses mengenal kata dalam kalimat. Membaca adalah keterampilan untuk menafsirkan suatu teks atau bacaan (Bastiono, 2007). Menurut Crawley dan Mountain (1995), membaca melibatkan banyak hal. Membaca tidak hanya aktivitas melafalkan tulisan, tetapi juga aktivitas visual dan berpikir. Pada tahap visual, proses membaca berupa menerjemahkan huruf ke dalam kata-kata lisan. Penerjemahan ini memerlukan proses berpikir. Sebagai suatu proses berpikir, membaca mencakup aktivitas pengenalan kata, pemahaman literal, interpretasi, membaca kritis, serta pemahaman kreatif. 
Prinsip-prinsip membaca menurut McLaughlin dan Allen (2007), meliputi: 1) membaca sebagai proses konstruktivitas sosial, 2) membaca menuntut adanya keseimbangan kemahiraksaraan, 3) guru harus memberi contoh dalam minat baca, 4) pembaca berperan aktif, 5) membaca dilakukan dengan penuh makna, 6) kebermanfaatan membaca dapat dirasakan secara langsung, serta 7) membaca dipengaruhi oleh perkembangan dan penguasaan kosakata.Minat baca dapat disinonimkan dengan motivasi untuk membaca. Rahim (2008) menyatakan bahwa minat baca merupakan keinginan kuat seseorang untukmembaca. Hal ini diwujudkan dalam bentuk usaha keras untuk memeroleh bahan bacaan. Dengan penuh kesadaran, bahan bacaan itu dibaca sampai selesai atau habis.Menurut Tarigan (1997) ciri anak yang memiliki minat baca tinggi: 1) berkeinginan untuk membaca, 2) bersemangat saat membaca, 3) biasa dan rutin dalam membaca, 4) setiap waktu luang dimanfaatkan dengan membaca, 5) memiliki koleksi buku bacaan, 6) berusaha mencari bahan bacaan, baik di perpustakaan maupun ditempat lain, 7) kegiatan membaca yang dilakukan selalu bertujuan, 8) memberi tanda dan mencatat hal penting yang ada di bacaan, 9) sadar diri bahwa membaca merupakan bagian dari belajar, serta 10) berdiskusi tentang hasil bacaan yang telah dilakukan.

Terdapat beberapa hambatan dalam menumbuhkan minat baca, 1) rendahnya budayamembaca, 2) besarnya pengaruh televisi, 3) adanya anggapan bahwa buku bukan prioritas, 4) minimnya fasilitas, 5) faktor keluarga (Kholianti, 2011). Banyak penelitian telah dilakukan. Hasil penelitian itu menunjukkan bahwa minat baca masyarakat masuk kategori rendah. Masyarakat cenderung malas untuk membaca. Belum lagi dengan maraknya program televisi. Masyarakat berasa semakin dimanjakan. Tanpa harus bersusah payah memahami sebuah teks, masyarakat telah dibantu oleh pembaca acara dalam memaknai sesuatu. Faktor penghambat lainnya adalah adanya anggapan bahwa memiliki banyak buku bukanlah sesuatu yang dapat dibanggakan. Masyarakat masih mengukur kesuksesan dalam bentuk harta benda yang bukan berupa buku. Di satu sisi, masyarakat Indonesia memang memiliki daya beli buku yang rendah. Oleh karena itu, hendaknya pemerintah memberi kemudahan atau fasilitas sehingga masyarakat menjadi mudah untuk membaca buku.

Faktor keluarga turut memengaruhi minat membaca seseorang. Hal ini dikarenakan keluarga sebagai tempat sekolah pertama dan utama sebelum tempat sekolah formal. Keluarga yang membiasakan kegiatan membaca dalam aktivitas sehari-hari pasti juga akan menjadi kebiasaan bagi anggota keluarga lainnya. Oleh karena itu, tidak salah jika minat membaca memang juga harus dibentuk dari keluarga. Siswati (2016) melakukan penelitian tentang minat baca mahasiswa semester 1 Fakultas Psikologi Univesitas Diponegoro. Data penelitian deskriptif ini diperoleh melalui angket dari 92 informan. Angket tersebut memuat 16 pertanyaan seputar: lama waktu membaca, jenis buku yang dibaca, 
serta koleksi buku yang dimiliki. Hasil penelitian menunjukkan bahwa $75 \%$ informan suka membaca dan hanya 52,2\% yang menempatkan pembaca sebagai hobi.

Nurhaidah (2016) meneliti dampak rendahnya minat baca mahasiswa PGSD Lampeuneurut Banda Aceh. Berdasarkan penelitian tindakan kelas yang dilakukan dapat disimpulkan bahwa rendahnya minat baca berdampak pada kedalaman pengetahuan dan keluasan wawasa sert rendahnya kemampuan inovatif dan kreatif. Beberapa cara yang dapat dilakukan untuk menumbuhkan minat baca, seperti: 1) meyakinkan mahasiswa bahwa gemar membaca merupakan hal yang sangat baik, 2) mahasiswa diberi tugas yang mengharuskan banyak membaca buku, serta 3) membiasakan mahasiswa untuk menabung dan membeli buku. Anugra, Yusup, dan Erwina (2013) melakukan penelitian tentang minat baca mahasiswa di UPT Perpustakaan ITB. Penelitian survei ini melibatkan 96 responden. Data diperoleh melalui angket, wawancara, kuesioner, dan studi pustaka. Adapun faktor dominan yang memengaruhi minat baca mahasiswa adalah lingkungan sosial yang kondusif. Minat membaca tidak hanya berasal dari diri mahasiswa, tetapi juga perlu dukungan dari lingkungan.

Penelitian ini akan menganalisis berbagai minat baca mahasiswa, baik faktor internal maupun eksternal. Penelitian ini diharapkan dapat memberi masukan, baik bagi mahasiswa sendiri, dosen, perpustakaan, maupun penyelenggara pendidikan lainnya. Mahasiswa adalah kaum cendekia. Sebagai seorang cendekia, mahasiswa dituntut untuk memiliki pengetahuan yang dalam. Salah satu cara untuk mendapat dan menambah pengetahuan adalah dengan membaca.

\section{METODE}

Penelitian ini menggunakan pendekatan deskriptif eksplanatif yang dilaksanakan selama Agustus sampai November 2018. Data diperoleh melalui angketdan wawancara tertutup (Cohen, 2000: 271). Populasi penelitian meliputi seluruh mahasiswa FITK IAIN Syekh Nurjati Cirebon. Adapun sampel penelitian berjumlah 100 mahasiswa yang dipilih secara acak dari 10 jurusan di IAIN Syekh Nurjati Cirebon. Data yang diperoleh dari angket akan dianalisis dengan menggunakan aplikasi SPSS. Data hasil wawancara akan dianalisis sebagai pendukung angket.

Validitas data dilakukan dengan triangulasi sumber, triangulasi metode, triangulasi peneliti, dan triangulasi teori (Moleong, 2010: 330). Triangulasi sumber dengan mengecek kebenaran status informan sebagai mahasiswa IAIN Syekh Nurjati Cirebon. Adapun triangulasi metode dilakukan dengan mengecek kebenaran metode penelitian yang digunakan. Triangulasi peneliti dilakukan dengan diskusi teman sejawat. Triangulasi teori dilakukan dengan pendapat para ahli. Penelitian ini dilakukan dari Maret sampai Oktober 2018. Adapun tahapan dalam penelitian meliputi: pertama, validasi instrumen penelitian oleh pakar. Kedua, mengumpulkan data melalui penyebaran angket dan diperkuat dengan wawancara. 
Ketiga, dilakukan pengelompokan data. Keempat, dilakukan analisis. Kelima, diambil simpulan.

PEMBAHASAN
Terdapat persamaan dan perbedaan diantara novel Para Pawestri Pejuang dan God's Callgirl yaitu sama-sama memperjuangkan hak perempuan dibidang ekonomi, beraspirasi, dan berumah tangga.

FITK merupakan fakultas yang memiliki jurusan paling banyak, yakni 10. Jurusan itu, meliputi: 1) PAI, 2) Tadris Matematika, 3) Tadris IPS, 4) Tadris IPA-Biologi, 5) Tadris Bahasa Inggris, 6) Pendidikan Bahasa Arab, 7) PGMI, 8) PIAUD, 9) Manajemen Pendidikan Islam, serta 10) Tadris Bahasa Indonesia. Informan yang mengisi data sebanyak 100 mahasiswa. Berikut ini data yang diperoleh dari kuesioner.

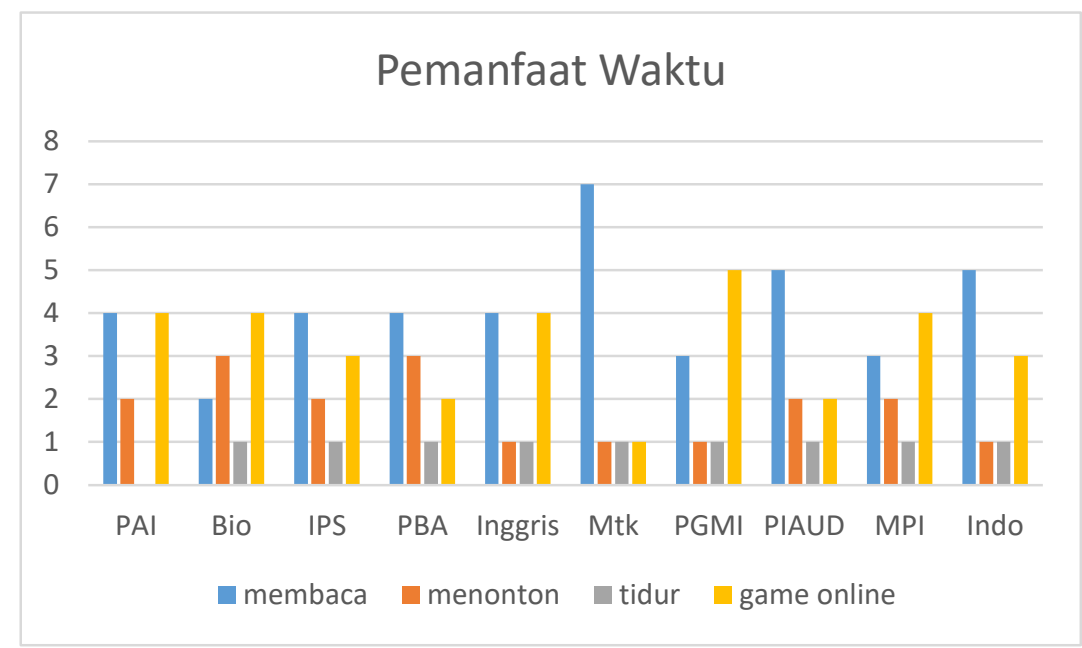

Gambar 1. Pemanfaatan Waktu

Berdasarkan data di atas dapat diketahui bahwa dari 100, hanya 41 mahasiswa yang mengisi waktu luang untuk membaca. Hal ini menunjukkan bahwa membaca belum menjadi kebutuhan. Seharusnya mahasiswa lebih banyak melakukan aktivitas membaca. Membaca perlu menjadi prioritas utama karena melalui membaca dapat menambah ilmu dan wawasan. Mahasiswa sebagai kaum intelektual selayaknya memiliki pengetahuan yang luas. Salah satu cara untuk mendapatkan pengetahuan itu adalah dengan banyak membaca. Mahasiswa banyak menghabiskan waktu luang dengan bermain game (32), tidur (9), dan menonton (18). Mahasiswa nampaknya juga terpengaruh oleh kemajuan teknologi, yaitu game online. Adapun alasan yang dikemukakan terkait dengan aktivitas itu adalah sebagai pelepas kepenatan. Bagi mahasiswa, bermain game online dianggap sebagai hiburan di tengah aktivitas mengerjakan berbagai tugas yang diberikan oleh dosen. Mahasiswa belum menyadari arti penting membaca sehingga justru banyak memanfaatkan waktu untuk kegiatan selain membaca. Selain game online, mahasiswa juga mengisi waktu luangnya dengan menonton. Adapun tempat menontonnya bervariasi. Ada yang menonton di 
gedung bioskop, di TV, di laptop, maupun di internet. Tontonan yang dilihat pun beragam. Ada yang melihat film, youtube, dakwah, dan komedi. Adapun alasan mahasiswa melakukan itu adalah sama seperti kegiatan game online, yakni untuk hiburan. Jawaban terakhir yang diberikan mahasiswa adalah tidur. Hanya beberapa mahasiswa yang memilih tidur sebagai aktivitas pengisi waktu luang. Dipilihnya tidur karena dianggap lebih bermanfaat dan murah. Mahasiswa tidak perlu mengeluarkan biaya untuk melakukan aktivitas ini.

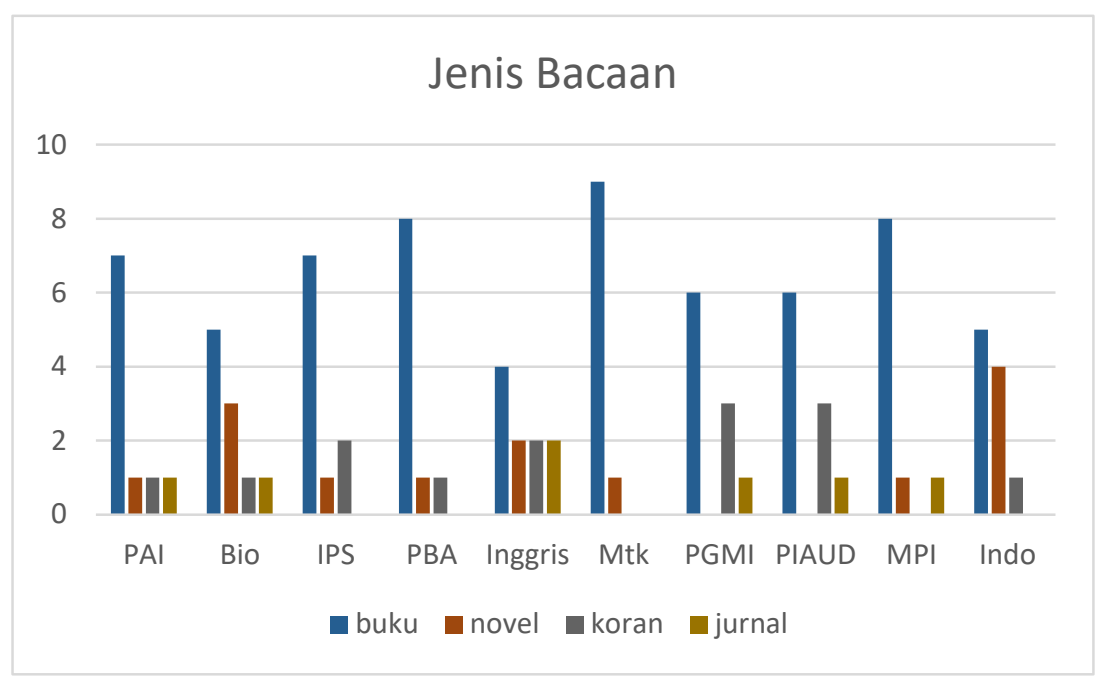

Gambar 2. Jenis Bacaan

Pertanyaan kedua pada angket terkait dengan kesukaan membaca yang ternyata jawaban para responden tidak sesuai dengan pertanyaan pertama. Dari 100, 75 mahasiswa menyatakan suka membaca. Artinya, secara umum mahasiswa memang suka membaca walaupun tidak selalu mengisi waktu luangnya dengan membaca. Hal yang menarik adalah bahwa dari 100 mahasiswa: hanya 7 yang membaca jurnal, 14 membaca koran, 14 membaca novel, dan 65 membaca buku. Artinya, mahasiswa belum terbiasa dengan membaca artikel ilmiah. Padahal artikel ilmiah sangat diperlukan, terutama dalam penulisan makalah sebagai salah satu tugas mata kuliah. Artikel juga sangat diperlukan ketika mahasiswa menulis skripsi. Hal ini karena artikel-artikel yang dimuat di jurnal biasanya adalah hasil penelitian. Oleh karena itu, alangkah baiknya jika mahasiswa sudah mulai dibiasakan untuk membaca artikel. Semakin sering mahasiswa membaca artikel, maka semakin banyak juga pengetahuan yang dimiliki terkait penelitian. Mahasiswa dapat belajar banyak, mulai dari sistematika penulisan dan metodologi yang digunakan. Kebiasaan membaca artikel juga diharapkan dapat membantu mahasiswa ketika nanti menyusun dan menulis skripsi. 


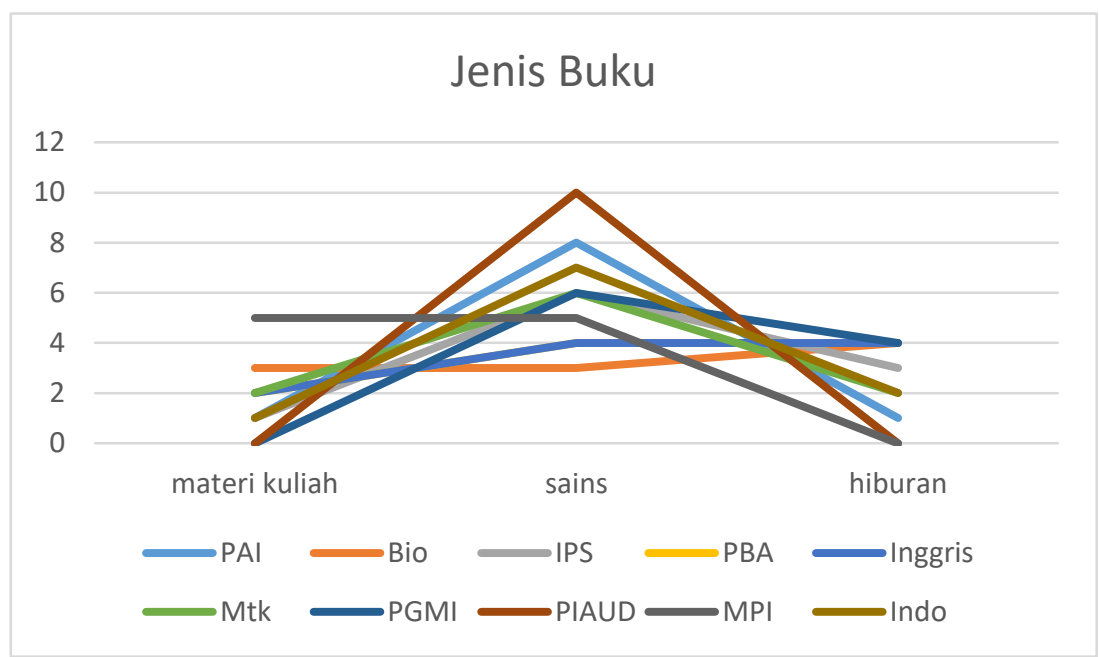

Gambar 3. Jenis Buku

Berdasarkan wawancara, buku yang dibaca mahasiswa: 59 berupa pengetahuan, 24 berupa hiburan, dan 17 berupa materi kuliah. Temuan ini sangat menarik. Artinya, mahasiswa tidak banyak membaca buku-buku yang terkait materi perkuliahan. Mahasiswa justru lebih banyak membaca buku pengetahuan umum. Sementara selama ini, dosen sering memberi tugas mahasiswa untuk membuat makalah. Makalah yang ditulis terkait dengan materi perkuliahan. Tentu saja pendalaman materi dapat dilakukan dengan banyak membaca buku yang direferensikan oleh dosen. Namun ternyata, mahasiswa justru tidak membaca buku-buku tersebut. Hasil wawancara menunjukkan bahwa sebagian besar dosen tidak menyampaikan buku-buku referensi yang harus dibaca sehingga mahasiswa tidak mencari dan membaca buku-buku tersebut. Padahal sebenarnya mahasiswa dapat mengetahui buku referensi tanpa harus disuruh oleh dosen. Hal ini karena setiap dosen sudah mengunggah Rencana Pembelajaran Semester (RPS) di aplikasi smart campus. Dosen diwajibkan untuk menggunggah RPS supaya mahasiswa dapat leluasa mengetahui dan mempersiapkan materi selama kontrak dengan mata kuliah tersebut. Mahasiswa juga mengungkapkan bahwa buku yang dibaca memiliki keterkaitan dengan materi perkuliahan walaupun tidak terdapat pada daftar buku yang direkomendasikan oleh dosen. 


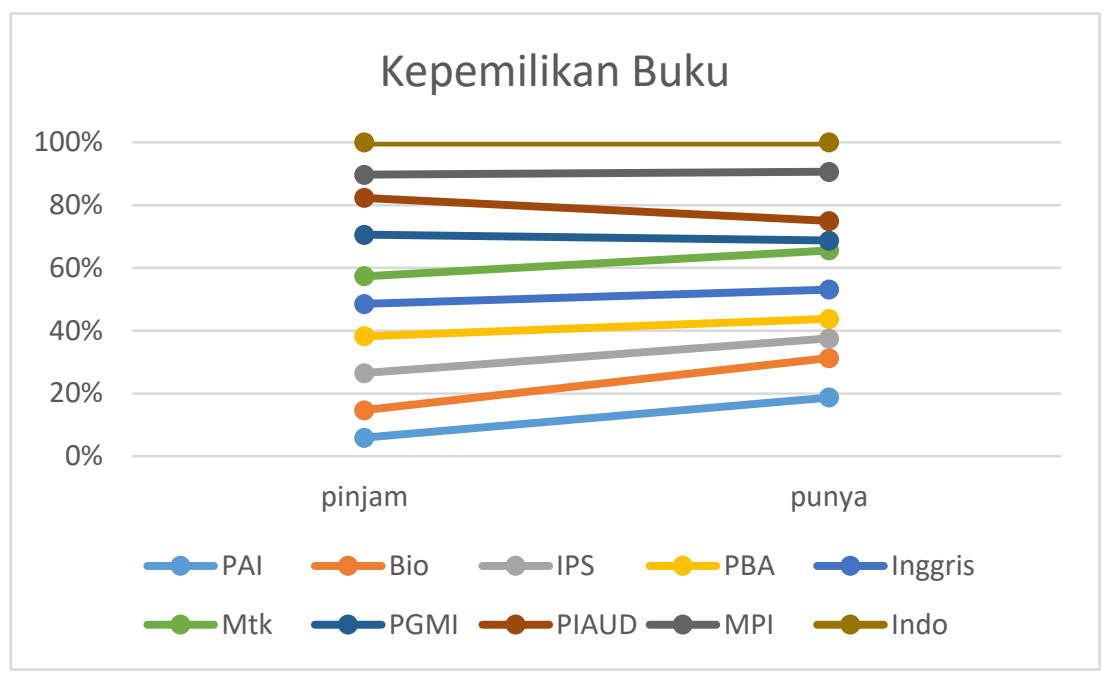

Gambar 4. Kepemilikan Buku

Data menunjukkan bahwa dari 100 mahasiswa, 68 buku yang dibacaoleh mahasiswa merupakan hasil meminjam. Hanya 32 yang merupakan milik sendiri. Adapun alasan mahasiswa karena keterbatasan dana untuk membeli buku. Mahasiswa hanya mengandalkan dari meminjam, baik dari perpustakaan maupun teman. Selain alasan dana, mahasiswa beranggapan bahwa materi kuliah atau bacaan-bacaan lain mudah diperoleh, terutama dari internet. Mahasiswa hanya perlu bermodal pulsa internet atau wifi. Oleh karena itu, mahasiswa tidak perlu repot-repot untuk membeli buku. Hal ini menggambarkan kurangnya motivasi mahasiswa dalam memiliki buku. Sebenarnya, jika mau. Mahasiswa dapat menabung dan uang yang terkumpul digunakan untuk membeli buku. Walau bagaimana pun, memiliki buku sangat dianjurkan bagi mahasiswa. Dalam sebuah buku, terkandung ide penulis secara utuh. Dengan membaca sendiri sebuah buku, akan memudahkan mahasiswa dalam memahami suatu pendapat. Sementara di internet, rerata merupakan ide yang sudah bercampur dengan ide penulis. Artinya, ide yang ditemukan di blog bisa jadi sudah merupakan perpaduan ide penulis buku dan ide penulis blog. Berdasarkan fakta tersebut, mahasiswa hendaknya diberi motivasi untuk memiliki buku, baik membeli sendiri maupun diberi atau hadiah. 


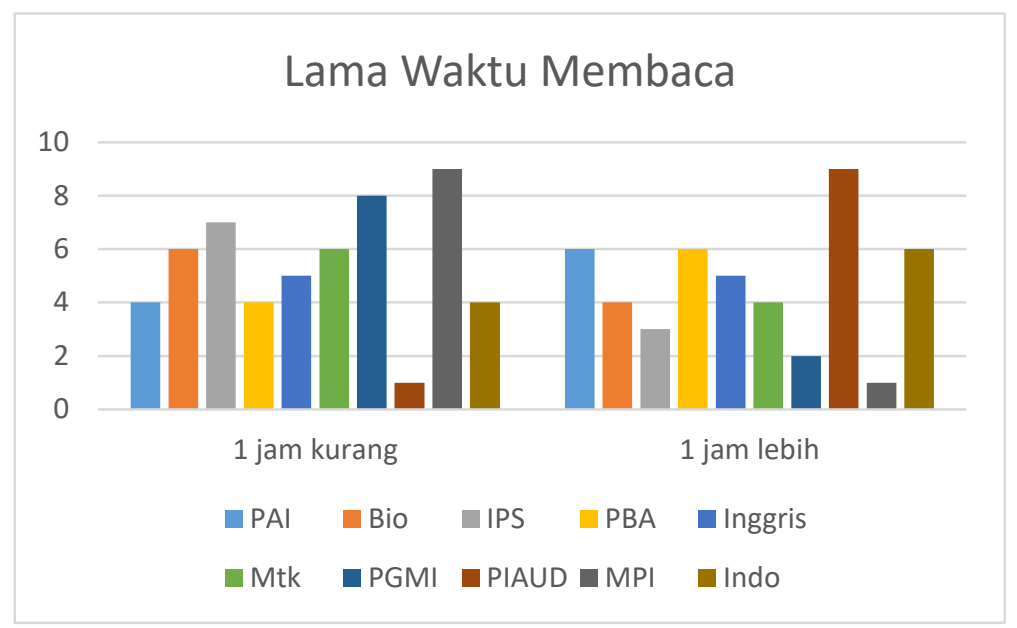

Gambar 5. Lama Waktu Membaca

Terkait lama waktu membaca, berdasarkan angket dapat diketahui bahwa 54 mahasiswa menghabiskan waktu kurang dari satu jam. Hal ini menunjukkan bahwa mahasiswa memang tidak suka membaca. Adapun dari hasil wawancara dapat diketahui bahwa jika membaca lebih dari satu jam, mahasiswa akan merasa mengantuk. Selain itu, mahasiswa juga merasa bosan dan pusing. Buku-buku yang dibaca berisi tentang sains. Buku sains berisi pengetahuan dan masuk dalam kategori buku berat. Oleh karena itu, jika membaca lebih dari satu jam, mata terasa panas. Walaupun sebenarnya, faktor mata yang terasa panas dapat diselesaikan dengan banyak sinar. Namun demikian, persoalan sebenarnya bukan pada mata, tetapi pada niat atau motivasi. Motivasi membaca yang rendah menyebabkan mahasiswa tidak bertahan lama dalam membaca. Hal ini tentu tidak akan terjadi jika buku yang dibaca berjenis hiburan, seperti novel atau cerpen. Bahkan mahasiswa akan menghabiskan seluruh waktu yang dimiliki demi menyelesaikan sebuah novel. Mahasiswa akan merasa penasaran dengan kisah yang disampaikan dalam novel. Penyajian novel juga membuat mahasiswa menikmati membaca dan menyelesaikan satu buku tersebut. Apalagi jika jalan cerita yang ada di buku tersebut sama dengan kisah pembaca, dalam hal ini mahasiswa. Hal inilah mungkin yang harus dilakukan para penulis buku sains sehingga mahasiswa tidak cepat mengantuk ketika membaca buku sains.

Bagian atas telah disebutkan bahwa sebagain besar mahasiswa tidak memiliki buku, melainkan meminjam. Adapun tempat peminjaman buku yang dimaksud adalah perpustakaan, yakni sebanyak 97 mahasiswa. Hal ini menunjukkan bahwa perpustakaan memiliki koleksi buku yang diperlukan oleh mahasiswa. Semua itu juga dibenarkan ketika dikonfirmasi melalui wawancara. Sebagian besar mahasiswa menyatakan bahwa sampai saat ini, perpustakaan memang merupakan tempat yang tepat untuk meminjam buku. Perpustakaan memiliki koleksi yang banyak. Namun demikian, mahasiswa juga menyampaikan bahwa koleksi buku di perpustakaan kurang baru. Artinya, perpustakaan hanya memiliki buku-buku cetakan lama.Sementara beberapa dosen kadang 
meminta buku terbitan terbaru. Selain itu, jumlah buku di perpustakaan juga relatif sedikit. Artinya, mahasiswa kadang harus berebut untuk meminjam sebuah buku.

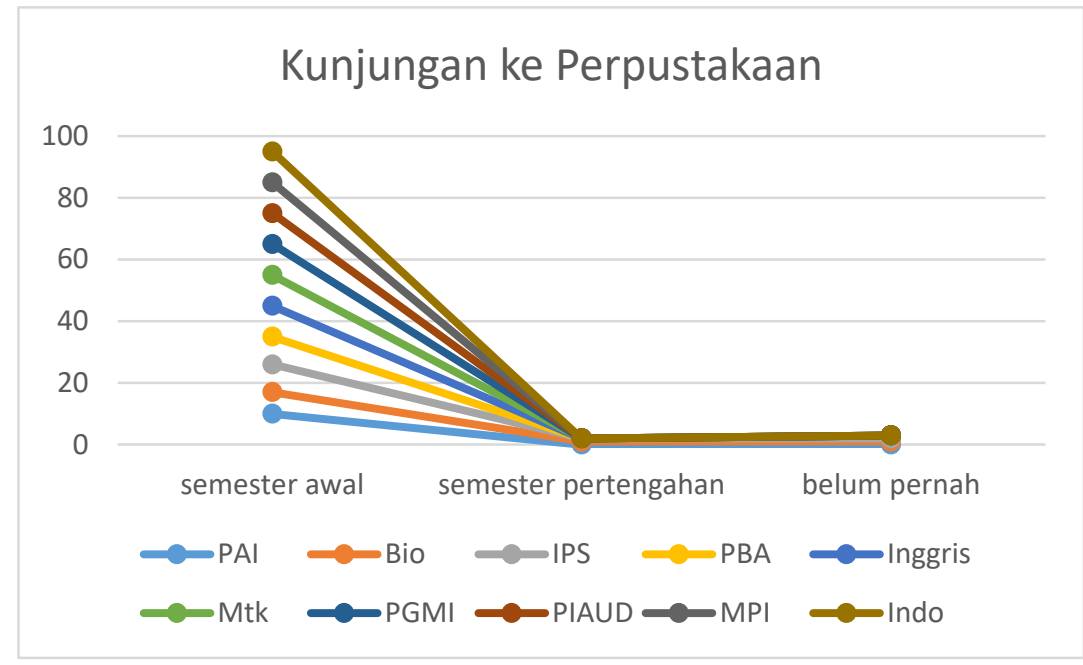

Gambar 6. Kunjungan ke Perpustakaan

Terdapat temuan yang menarik, yakni sebagian besar mahasiswa mengunjungi perpustakaan di semester awal. Setelah dikonfirmasi, ternyata hal ini dilakukan karena mahasiswa masih mengalami penyesuaian. Rerata mahasiswa berasal dari luar Cirebon sehingga tidak atau belum mengetahui buku-buku yang harus dimiliki. Selain itu, mahasiswa memang tidak memiliki koleksi buku terkait jurusan yang diambil. Oleh karena itu, mahasiswa memanfaatkan perpustakaan sebagai tempat untuk meminjam buku. Menurut mahasiswa, meminjam buku di perpustakaan lebih nyaman daripada harus membeli. Walaupun terdapat kendala pada saat meminjam buku di semester awal. Salah satu syarat meminjam buku adalah menunjukkan kartu mahasiswa. Pada semester satu, mahasiswa belum mendapatkan kartu mahasiswa. Kartu tersebut biasanya baru diperoleh pada akhir semester dua. Hal inilah yang kadang membuat mahasiswa malas untuk meminjam buku di perpustakaan, walaupun di perpustakaan IAIN sendiri. Dari data di atas terlihat bahwa terdapat tiga mahasiswa yang belum pernah mengunjungi perpustakaan. Setelah dikonfirmasi, ternyata alasan mahasiswa adalah karena tidak mau repot. Hal ini seperti telah diungkapkan sebelumnya bahwa ketika hendak meminjam buku, mahasiswa harus menunjukkan kartu mahasiswa. Sementara mahasiswa tersebut belum memiliki, maka memilih untuk tidak meminjam di perpustakaan. Alasan lain yang dikemukakan adalah minta tolong temannya. Artinya, buku-buku tersebut biasanya digunakan untuk menyelesaikan tugas kelompok. Oleh karena itu, terdapat mahasiswa yang kurang bertanggung jawab dengan hanya mendompleng nama pada tugas kelompok yang diberikan oleh dosen.

Selain perpustakaan pusat IAIN Syekh Nurjati Cirebon, mahasiswa juga meminjam buku di perpustakaan kota maupun 
perpustakaan daerah. Berdasarkan data yang terkumpul, sebagian besar mahasiswa pernah meminjam buku di perpustakaan kota dan hanya 14 mahasiswa yang belum pernah mengunjungi kedua perpustakaan tersebut. Ketika dikonfirmasi, mahasiswa menyatakan bahwa perpustakaan IAIN tidak memiliki koleksi buku-buku tertentu. Adapun buku yang dimaksud adalah buku yang terkait dengan karya sastra klasik. Misalnya mahasiswa Jurusan Tadris Bahasa Indonesia yang mendapat tugas dari dosen untuk menganalisis karya sastra klasik. Setelah dicari di katalog perpustakaan IAIN, ternyata buku yang dimaksud tidak ada. Oleh karena itu, mahasiswa terpaksa mencari atau meminjam di tempat lain. Adapun alasan ketidakberadaan buku tersebut antara lain karena Jurusan Tadris Bahasa Indonesia adalah jurusan baru sehingga perpustakaan belum memiliki koleksi buku yang dimaksud. Oleh karenanya, perpustakaan pusat IAIN lebih banyak mengoleksi buku-buku keilmuan terkait agama. Namun demikian, seiring berjalannya waktu, perpustakaan pusat IAIN mulai menambah jenis dan jumlah koleksi buku sesuai kebutuhan berbagai jurusan yang ada, baik rumpun agama maupun lainnya. Hal ini dilakukan dengan pendataan kebutuhan buku yang dilakukan pengelola perpustakaan kepada pengelola jurusan.

Pertanyaan penelitian berlanjut pada jumlah buku yang pernah dipinjam oleh mahasiswa. Ternyata, jumlah buku yang dipinjam bervariasi. Namun demikian dapat dikelompokkan menjadi dua, yakni lebih dari 10 buku dan kurang dari 10 buku. Berdasarkan data yang terkumpul, 90 mahasiswa menyatakan pernah meminjam buku dengan jumlah kurang dari 10 judul. Sisanya menyatakan pernah meminjam lebih dari 10 judul buku. Merujuk dari data ini dapat disimpulkan bahwa mahasiswa hanya sedikit membaca buku. Sepuluh judul buku merupakan jumlah yang kecil bagi mahasiswa. Seharusnya mahasiswa dapat meminjam lebih dari itu. Jika tugas makalah yang dibuat oleh seorang mahasiswa wajib memuat minimal lima referensi, maka setidaknya untuk satu mata kuliah sudah diperlukan lima buku. Rerata dalam satu semester, mahasiswa mengambil 22 sks atau 10 - 11 mata kuliah. Jika satu mata kuliah memerlukan minimal lima referensi, maka hendaknya dalam satu semester mahasiswa dapat membaca atau meminjam 50 -55 judul buku. Namun faktanya tidak demikian. 


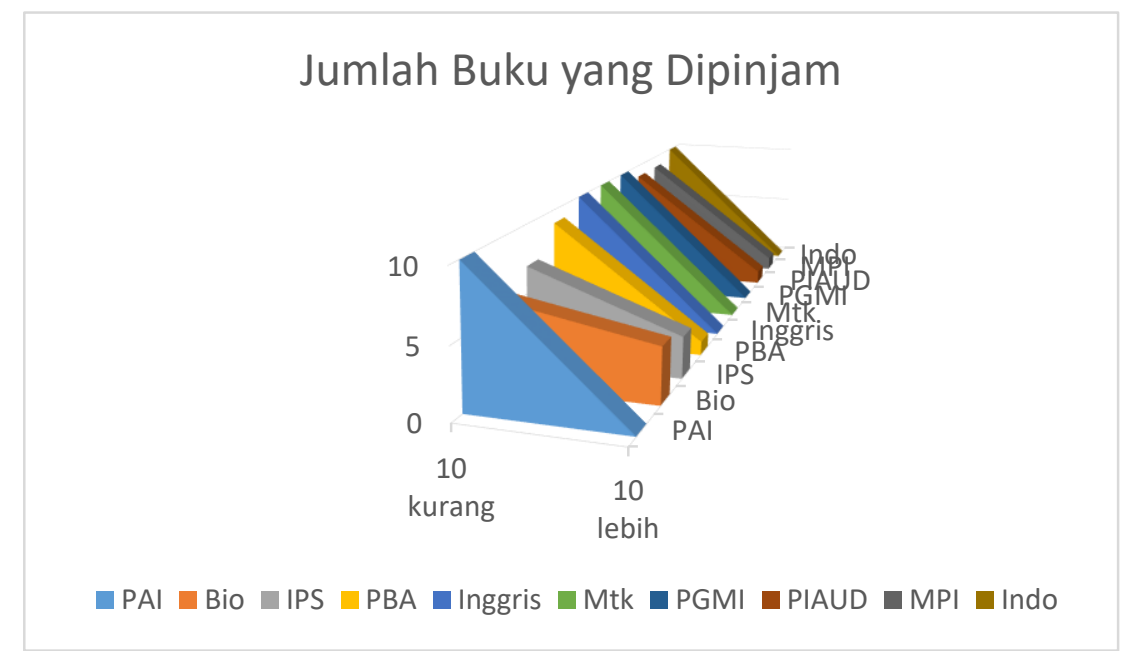

\section{Gambar 7. Jumlah Buku yang Dipinjam}

Walaupun meminjam di perpustakaan, ternyata 91 mahasiswa menyatakan memiliki koleksi buku di rumah. Namun jumlahnya tidak banyak. Berdasarkan data yang terkumpul 66 mahasiswa memiliki koleksi buku lebih dari 15 judul sedangkan 33 mahasiswa lainnya memiliki buku kurang dari 15 judul. Artinya, untuk ukuran mahasiswa, jumlah tersebut masuk dalam kategori rendah. Setelah dikonfirmasi, mahasiswa menyatakan bahwa koleksi buku yang dimiliki memang sedikit. Hal tersebut terkait dengan dana yang dimiliki. Mahasiswa ingin dapat memiliki buku sebanyakbanyaknya. Namun kemampuan finansial tidak mendukung itu. Walau bagaimana pun, memiliki buku sendiri lebih nyaman daripada harus meminjam. Dengan memiliki buku sendiri, mahasiswa dapat leluasa membaca tanpa harus dibatasi oleh waktu. Seiring perkembangan teknologi informasi, kepemilikan buku cetak dapat digantikan dengan buku elektronik. Oleh karena itu, mahasiswa mengoleksi buku di laptop atau flashdisc. Buku-buku tersebut diperoleh dari mencari sendiri, diberi teman, atau juga diberi oleh dosen.

\section{Jumlah Koleksi Buku di Rumah}

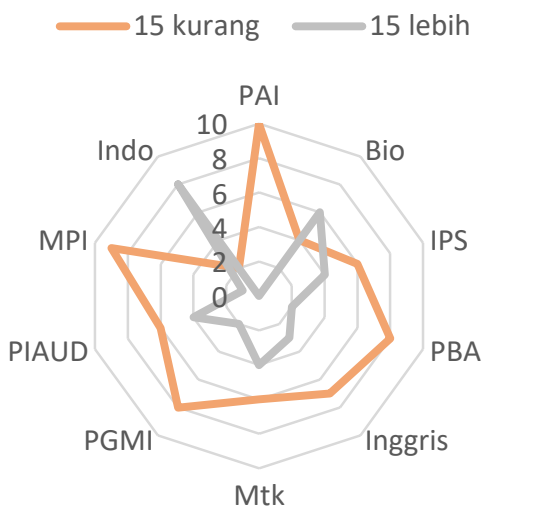

Gambar 8. Jumlah Koleksi Buku di Rumah 
Dari 15 buku yang dikoleksi di rumah, 64 buku berjenis nonfiksi dan 36 buku berjenis fiksi. Hasil konfirmasi kepada mahasiswa dapat diketahui bahwa buku nonfiksi yang dimaksud, meliputi: materi kuliah dan referensi yang terkait perkuliahan. Adapun buku fiksi yang dimaksud, meliputi: cerpen dan kumpulan cerpen. Artinya, mahasiswa berusaha untuk memiliki buku-buku referensi yang terkait dengan materi kuliah. Buku-buku yang berusaha untuk dimiliki biasanya yang bagi mahasiswa masuk dalam kategori sulit. Berbagai mata kuliah yang diambil oleh mahasiswa dapat dikategorikan menjadi tiga, yakni: mudah, sedang, dan sulit. Mahasiswa berusaha untuk memiliki buku atau referensi mata kuliah yang masuk kategori sulit. Hal ini karena mahasiswa memerlukan waktu baca yang lebih lama untuk mempelajari materi tersebut sehingga jika jika hanya meminjam di perpustakaan, akan terepotkan dengan aktivitas memperpanjang masa peminjaman. Secara psikologi, hal ini akan berpengaruh terhadap pemahaman mahasiswa terhadap materi tersebut. Hal ini berbeda dengan ketika memiliki buku sendiri. Selain faktor waktu, dengan memiliki buku sendiri, mahasiswa bebas untuk memberi catatan pada buku tersebut.

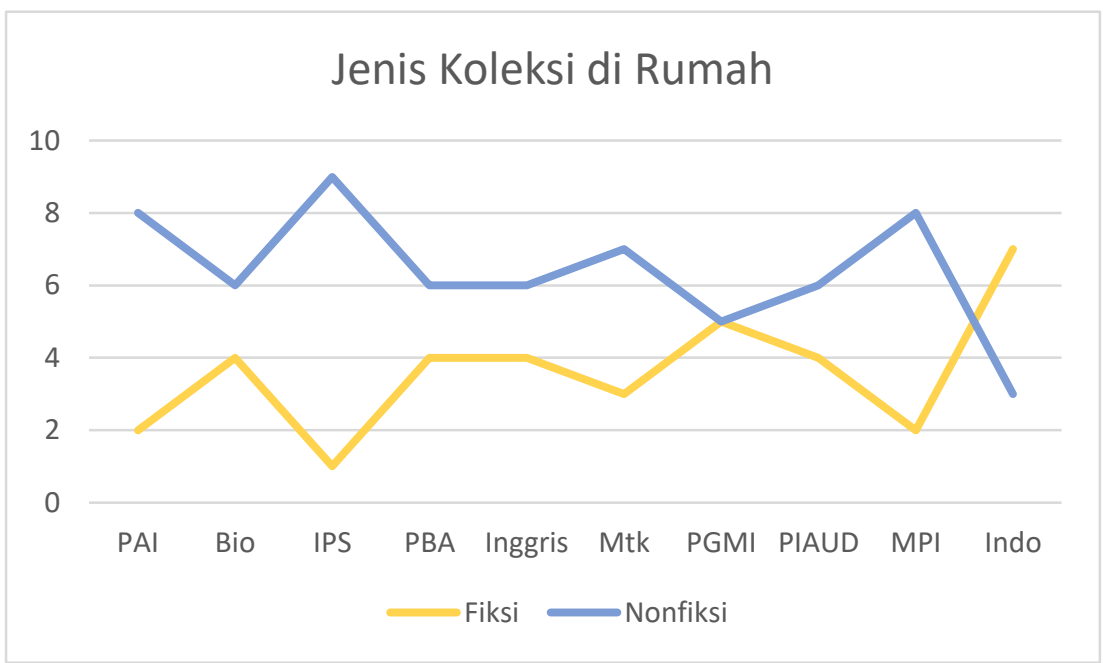

Gambar 9. Jenis Koleksi di Rumah

\section{SIMPULAN}

Berdasarkan data dan analisis di atas dapat disimpulkan bahwa minat baca mahasiswa FITK IAIN Syekh Nurjati Cirebon masih tergolong rendah. Hal ini dapat diketahui dari: 1) aktivitas yang dilakukan ketika memiliki waktu luang, 2) jumlah buku yang telah dibaca, 3) kunjungan ke perpustakaan, serta 4) jenis buku yang dibaca. Adapun faktor yang memengaruhi minat baca mahasiswa FITK IAIN Syekh Nurjati Cirebon adalah motivasi dari dalam diri dan motivasi dari luar, seperti: ketersediaan dana dankoleksi buku. 
DAFTAR PUSTAKA

Anugra, H., Yusup, P.M., \&Erwina, W. 2013. "Faktor-Faktor Dominan yang Mempengaruhi Minat Baca Mahasiswa Survei Eksplanatori tentang Minat Baca Mahasiswa di UPT Perpustakaan ITB". Jurnal Kajian Informasi dan Perpustakaan Vol.1, No.2, Desember 2013, hal. 137-145 ISSN: 2303-2677

Bastiono. 2007. Pembinaan minat baca. Jakarta: Universitas Terbuka.

Chaplin, J. P. 2008. Kamus Psikologi Lengkap. Jakarta: PT Raja Grafindo.

Cohen, L., et al. 2000. Research Methods in Education. Great Britain: TJ International Ltd, Padstow, Cornwall.

Crawley \& Mountain. 1995. Language Development: An Introduction. New York: Macmillan Publishing Company.

Kamus Besar Bahasa Indonesia. 2015. Kementerian Pendidikan dan Kebuadayaan Republik Indonesia.

Kholiati. 2011. Hubungan antara FrekuensiKunjungan

Perpustakaan Sekolahdengan Minat Baca Siswa Kelas IV di SD Negeri 3 Sentolo, KulonProgo Tahun Ajaran 2010/ 2011. Skripsi. PGSD UNY.

Kompas. 2016. Minat Baca Rendah: Mayoritas Warga Indonesia Hobi MenontonTelevisi http://regional.kompas.com/read/ 2016/04/28/21020061/Minat.Bac a.Rendah.Mayoritas.Warga.Indon esia.Hobi.Nonton.Televisi.
McLaughlin, M. \& Allen. 2002. Guided Comprehension. New York: International Reading Association.

Moleong, L. J. 2010. Metode Penelitian Kualitatif. Edisi Revisi. Bandung: Remaja Rosdakarya.

Nurhaidah, M. I. M. 2016. "Dampak Rendahnya Minat Baca di Kalangan Mahasiswa PGSD Lampeuneurut Banda Aceh Serta Cara Meningkatkannya". Jurnal Pesona Dasar Pendidikan Guru Sekolah Dasar (PGSD) Universitas Syiah Kuala Vol. 3, No.4, Oktober 2016, hal. 1-11, ISSN: 2337-9227.

Prasetyono, D. S. 2008. Rahasia Mengajarkan Gemar Membaca Pada Anak Sejak Dini. Yogyakarta: Think.

Rahim, F. 2008. Pengajaran Membaca di Sekolah Dasar. Jakarta: BumiAksara.

Siswati. 2016. "Minat Membaca pada Mahasiswa (Studi Deskriptif pada Mahasiswa Fakultas Psikologi UNDIP Semester I)" Prosiding Seminar Asean Psychology dan Humanity pada 19-20 Februari 2016 di Universitas Muhammadiyah Malang.

Tarigan, H. G. 1997. Membaca Sebagai Suatu Keterampilan Berbahasa. Bandung: Angkasa 